\section{Modular Morphogenesis: Determinate Rhythmic Budding in Hydra}

\section{Stanley Shostak*}

Department of Biological Sciences, University of Pittsburgh, USA

\begin{abstract}
The last half century of research on hydra's morphology and morphogenesis has opened up a cornucopia of possibilities for future investigations. A preeminent question is, do the dynamics of hydra's development and maintenance apply to other metazoan's growth, physiology and pathology?
\end{abstract}

Under favorable laboratory conditions, hydras achieve an optimal configuration and maintain a steady-state. In this state, continuous cell division in the body column is matched by the rhythmic removal of excess parental cells as buds in the budding region.

Since, hydra's buds form with the same number of tentacles present on animals in their optimal configuration, hydra's form and its stability would seem built into buds. Depending on feeding schedule and temperature, parental cells are produced at different rates and move toward the budding region accordingly. These parental cells seem to accumulate in modules that upon filling up (with approximately 15,000 parental cells) sprout as incipient buds.

Modules would form where gastric region cells moving down the body column collide with peduncle cells moving up. The circular muscle fibers of gastrodermal cells would seem to be reconfigured at this junction, and their contraction around modules project incipient bud sprouts outward, breaking with parental polarity and lineal parental constraints. The sprout adds new substratum (mesoglea); epithelial cells form the bud's head, body column, and foot; individual interstitial cells become the stem-cells of nerve, gland, cnidoblast and sex cells.

The concept that symbiogenic lies at the starting point of Cnidaria as well as the evolution of other metazoans suggests that what is true for hydra is true elsewhere. In addition to looking for remnants of cnidarian genomes in bilaterians, researchers might look at the morphogenesis and maintenance of epithelial appendages and car-

*Corresponding author: Stanley Shostak, Department of Biological Sciences, University of Pittsburgh, USA, Tel: +1 4126244266; E-mail: sshostak@pitt.edu

Citation: Shostak S (2019) Modular Morphogenesis: Determinate Rhythmic Budding in Hydra. J Cell Biol Cell Metab 6: 017.

Received: May 14, 2018; Accepted: May 22, 2019; Published: May 29, 2019

Copyright: @ 2019 Shostak S. This is an open-access article distributed under the terms of the Creative Commons Attribution License, which permits unrestricted use, distribution, and reproduction in any medium, provided the original author and source are credited. cinoma's metastatic units for evidence reminiscent of hydra's habit of discarding excess parental cells with pulsatory regularity. Researchers might also look at the accumulation and rejection of individual cells in vascular and connective tissue, lymphomas and sarcomas, reminiscent of hydra's rejection of interstitial cells in buds.

\section{Introduction}

Many years ago, hydra's highly touted morphological simplicity attracted me to pursue research on its cellular proliferation and differentiation, morphogenesis and regeneration [1-4]. Recently, Cnidaria's ancient roots prompted me to suggest that symbiogenic origins lie behind hydra's morphogenic cellular interactions [5-11].

In the intervening years, a plethora of research on hydra has focused my concerns in two fundamental areas. (1) Under laboratory conditions, hydras are known to produce cells continuously, but hydras only sprout buds discontinuously. How then is the process of producing cells regularly transformed into the process of making buds at intervals? (2) Under optimal laboratory conditions, hydras achieve a steady state, neither elongating nor shrinking. At the same time, these steady-state hydras sprout bud primordia that elongate, develop a head of tentacles and hypostome, a body column containing differentiating cells, and a terminal adhesive pad before detaching as buds. How is budding related to the parent's steady state?

Not being one to hedge on speculation, I have placed hydra's symbiogenic origins at the starting point of hydra's morphogenic characteristics and have suggested the relevance of dual origins in hydras to the development and maintenance of organ systems and their appendages in other organisms [6-9]. Over the years, I've even gone so far as to suggest that the breakdown of integration in symbiogenesis pathways accounts of pathogenesis such as that seen in the cancers in vertebrates [12-14].

\section{Hydras Produce Cells Continuously but Buds Sprout Discontinuously}

Hydra has two tissues, an epithelial and a uniquely cellular. An outer epithelium of epidermal cells ("Ectodermal epithelial cells," epitheliomuscular cells, ectoderm) and an inner epithelium of gastrodermal cells ("Endodermal gland cells") lie on either side of the mesoglea (matrix or Extracellular Material [ECM]). Hydra's cellular tissue consists of interstitial (basal cells, neoblast) concentrated in intercellular spaces between hydra's epidermal cells [15-18].

Hydra's epithelial cells constitute self-sustaining cell populations that differentiate locally into non-dividing cells of the head (hypostome and tentacles) and foot (lower peduncle and basal adhesive disk). In tentacles, some epidermal cells differentiate as battery cells that acquire and orient cnidocytes (stinging cells) bearing cnidocysts, while in the foot epidermal cells differentiate as adhesive cells in a terminal pad. 
In contrast, interstitial cells have stem-cell properties, dividing and giving rise to cells that become nerve, gland cells and cnidoblasts that subsequently differentiate into various cnidocytes [10]. Cnidocytes may migrate from the body column to tentacles where they function in predation and defense [19]. Other interstitial cells become sperm and egg $[20,21]$.

\section{Hydra's Dividing Cells}

Cell proliferation is restricted to cells in the animal's body column. The epidermis has a higher frequency of mitotic figures and supports a greater rate of incorporation of tritiated thymidine than the gastrodermis consistent with the smaller size of epidermal cells compared to gastrodermal cells [1-3,15,22-26].

The pattern and rates of cell division along the body column may differ by species. Paul Brien deserves credit for the discovery of "La zone de croissance sous hypostomiale" (Brien's sub-hypostomal growth zone) in Hydra fusca, and Allison Burnett for stretching Brien's growth zone to the gastric and budding regions in $H$. viridis and H. pseudoligactis (H. canadensis) [27,28]. In H. littoralis, a distal zone of elevated mitotic activity appears among epidermal epitheliomuscular cells, but cell proliferation peaks in the budding region for interstitial cells and gastrodermal epitheliomuscular cells $[15,16,23,24,29]$.

\section{Hydras Regulate Their Dimensions}

Hydra's buds elongate while attached to parents through the acquisition of parental cells and intrinsic growth $[2,3,30]$. With adequate and regular feeding, detached hydra buds cultured in incubators at suitable temperatures, reached their maximum lengthen and begin budding after about two weeks [31]. These hydras will remain at this maximum length and sustain this budding rate thereafter as long as conditions remain the same.

These hydras may be said to have reached an equilibrium at which their cell number and the number of buds present per parent, are approximately constant (albeit not indefinitely: i.e., members of the Oligactis group of hydras (H. oligactis, $H$. oxycnida, $H$. canadensis) age and die following the induction of sexuality by lowered temperature $[4,32]$.

Hydras lengthened by grafting additional gastric regions into a body column will shrink through excess budding and hydras shrunken, for example, by starvation or following the experimental elimination of interstitial cells by any of a variety of treatments (colchicine, nitrogen mustard, hydroxyurea, urethane, or lowered temperature) will elongate following the resumption of feeding and restoration of interstitial cells [12,33-39]. Moreover, these hydras will resume budding.

\section{Hydra's Body Cells Move toward the Budding Region}

Wherever they are produced, body cells converge toward the budding region $[3,15,16,23,24,40]$. The mesoglea would seem to be a substratum for this cell movement rather than a glue holding the epithelial layers together, since epidermal cells move faster than their larger gastrodermal counterpart $[1,3,15,23,24]$. It would seem that the longitudinal muscle extensions of epidermal cells aid the cells crawling over the mesoglea [41]. Indeed, epidermal cells have been seen migrating over experimentally denuded mesoglea [42].

\section{Hydras Employ Parental Cells in Bud Sprouts}

Budding rates are proportional to overall rates of cell division rather than the rate in the budding region $[15,43,29]$. In Hydra viridis (Chlorohydra viridissima) the rate of cell division among gastro dermal (digestive) cells in freshly detached buds is the same as the rate on buds still on parents $[3,44]$. Thus, neither cell division in the budding region nor on buds is accelerated. Budding, it would seem, takes place in the budding region with cells produced on the parent's body column following their movement toward and accumulation in the budding region.

\section{Hydra Buds from Modules}

Since parental body size would seem to be an intrinsic quality of hydras it would not be surprising if the size of parents is anticipated by the size of buds. Data in Figure 1 are consistent with the possibility that hydra's buds sprout from modules of uniform size. These modules incorporate epithelial and interstitials cells sequestered in the budding region. Indeed, under favorable and constant laboratory conditions, parent hydras would form more or less uniform modules and hence identical buds.

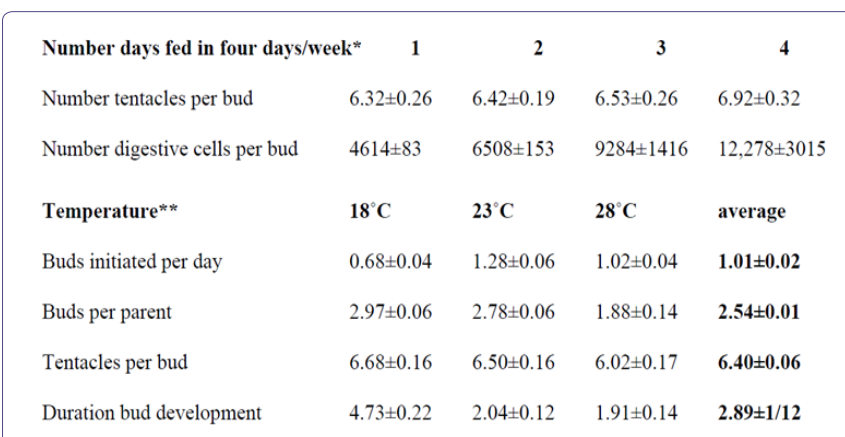

Figure 1: Buds, budding, and tentacle numbers as functions of feeding schedule and temperature.

*Shostak S (1979) Digestive cell and tentacle number in freshly detached buds of Hydra viridis. Int J Invert Reprod 1: 167-78.

**Shostak S (1981) Variation in Hydra's tentacle numbers as a function of temperature. Int J Invert Reprod 3: 321-31.

\section{The Module}

Bud modules of a constant size must somehow be isolated from adjacent parental tissue. In well-fed hydras cultured at optimal temperatures, new modules would fill up in the budding region with precise numbers of parental cells at the constant rhythm determined by the rate of cell division on the parent.

Figure 1 shows that hydras at equilibrium (cultured at $21^{\circ} \mathrm{C}$ ) fed one to four days a week produce buds with about six tentacles (between 5 and 7). Tentacle number for buds of hydras fed on these schedules does not differ significantly although larger animals present among those fed more often tend to produce buds with slightly more tentacles (i.e., the regression of tentacles/per feeding days differed significantly [44]). Later, the bud's tentacle number will not change from the number present on the sprouting bud (with the exception of hydras fed four (or more) days a week that may add an additional tentacle).

In contrast to the relative constancy of tentacle numbers, hydras fed more days a week detached buds with statistically significant 
more (digestive ${ }^{1}$ ) cells than hydras fed fewer days a week (Figure 1). The number of cells present on buds, therefore, does not determine the number of tentacles within a range of five to seven. The number of tentacles per bud is a built-in species characteristic.

Figure 1 also shows results for hydras at equilibrium and cultured at different temperatures (fed three days a week) [45]. The results indicated that $23^{\circ} \mathrm{C}$ is optimal for the number of buds initiated per day. Compared to hydras cultured at $23^{\circ} \mathrm{C}$, the three characteristics of budding observed - number of buds per parent, number of tentacles per bud, and duration of bud development - increase at the lower temperature $\left(18^{\circ} \mathrm{C}\right)$ and trail off at the higher temperature $\left(28^{\circ} \mathrm{C}\right)$.

Combined data in Figure 1 provide a picture of budding hydras filling modules at equilibrium: At temperatures of $21-23^{\circ} \mathrm{C}$, animals fed 3-4 days a week support two to three growing buds at a time, add slightly more than one bud a day that develops and detaches after two days with 6 to 7 tentacles and about 10,000 digestive cells.

\section{How Many Parental Cells Comprise a Module?}

One may answer this question with data in Figure 1 and assumptions about the average rate of cell division in hydras fed on different schedules. The 12,000 digestive cells present in freshly detached hydras produced on parents fed 4 days a week could be produced in two days by an initial mass of 2000-3000 digestive cells dividing twice a day. Likewise, the 6500 digestive cells present in freshly detached buds of parents fed 2 days a week would be produced by 2000-3000 digestive cells dividing once every day, and the 4000-5000 digestive cells present in buds from parents fed one day a week would be produced by about 2000-3000 digestive cells dividing once in two day.

Thus, the bud module would contain 2000-3000 digestive cells at the initiation of bud development in parents fed one to four days a week (and maintained at $21-23^{\circ} \mathrm{C}$ ). If the number of digestive cells is half the number of epidermal cells and the entire epithelium is half the size of the interstitial cell number, then a bud primordium would consist of about 15,000 cells.

Intriguingly, an estimate of 200-600 digestive cells found in tentacle rudiments during regeneration is consistent with the estimate of 2000-3000 digestive cells present in bud modules [46]. Given six to seven tentacles per bud, a bud module of 2000-3000 cells could support the initiation of six to seven tentacles in the developing bud (Figure 1).

Epithelial cells involved in the bud's foot formation and bud detachment, however, would seem disconnected from the greater part of the bud module. Buds just beginning to develop on animals treated briefly with colchicine or Colcimid form double headed animals with one original head and one retained bud $[47,48]$. If the colchicine or Colcimid inhibited cell division in the bud rudiment, it would seem that epithelial cell division is required for foot development and detachment.

\section{Bud Morphogenesis}

Bud modules would seem to break with parental symmetry possibly as a result of the budding region occurring at the juncture of the gastric region and peduncle. The reorientation of circular gastro

1. Digestive cells were used because in Hydra viridis these cells are uniquely and unambiguously identifiable in isolated cell smears, since, unlike all other cells, digestive cells bear retractile symbiotic algae. dermal musculature may be disturbed at this juncture, hence, encircling the module, and upon contraction thrust a bud outward perpendicular to the parent's long axis [49].

New mesogleal components are added as bud sprouts move outward and undertake independent development. The budding region is the site of local production of new mesogleal components $[2,40,49,50]$. Indeed, "the mesoglea [is] dramatically remodeled...at sites of tissue evagination", [40], and "no loss of ECM occurs before the time of bud emergence. Rather, the ECM is continuous at the sites of bud formation and what occurs is simply an increase in the expression of... [mesogleal components] as evagination of the bud progresses... [B] efore evagination of the bud occurs... upregulation of at least... [one mesogleal components] has already occurred. High expression of both basement membrane and interstitial matrix components occurs throughout all stages of bud formation [51]".

Beyond epithelia, interstitial cells play an essential role in budding. Indeed, they are required for the eruption of a bud module into a developing bud, since hydras deprived of their interstitial cells (known as "epithelial hydras"; do not sustain budding. Epithelial hydras may enlarge and form supernumerary tentacles when force-fed, but epithelial cells alone do not restore interstitial cells or the products of interstitial cell differentiation [39,52].

\section{The Evolution of Cnidaria: Symbiogeny and Budding}

In the past, symbiogeny - the joining of formerly separate epithelia-like and ameba-like eukaryotes - has been offered as a "central principle of evolution" and major player in the unification of metazoans $[6,7,53]$. Indeed, symbiogeny might well have provided a creative mechanism that working with competition enhanced metazoan evolution and racked up its pace.

Symbiogeny would explain the origin of many bilaterian tissues with preponderantly epithelial qualities (epidermis and intestinal lining exhibiting intercellular attachment sites and producing external lamella) as well as tissues composed of unattached cells (such as connective, mesenchymal and vascular tissues) secreting extracellular material, exhibiting phagocytosis, performing cell movement through a medium and across cellular barriers, and recruiting related cells to sites of cell differentiation.

Symbiogeny does not reclaim Ernst Haeckel's Biogenetic law: "Ontogenesis is a brief and rapid recapitulation of phylogenesis" to explain physiological functions of heredity (generation) and adaptation (maintenance) $[8,9,13,54]$. Rather, symbiogeny claims that separate origins of tissue would inevitably leave their marks on ontogeny and traces on development and homeostasis.

Remarkably, symbiogeny suggests how creative enterprises can come out of tissues' "separate but equal" combination and sharing of functions. For example, epithelia contribute to hydra's growth and elongation, to tentacle and hypostome formation, adhesive pad differentiation and detachment, while interstitial cells are essential for the eruption of buds and the differentiation of nerve, gland, sex cells and cnidocytes [55]. Symbiogeny suggests how organisms coming together and cooperating creatively in evolution, reaching beyond the parameters of competition and producing eumetazoans with new traits. 
What is so special about budding in hydra is that the epithelia and interstitial cells cooperate in the formation of buds and thus in the maintenance of optimal parental size while co-opting excess parental cells in asexual reproduction. Instead of non-adaptive elongation, hydras maintain their adaptive configuration through the judicious rejection of excess cells in buds.

\section{Symbiogeny and Cancer}

Finally, hydra may have something to teach us about tumors [33]. Indeed, budding might yet serve as a paradigm for metastasis $[5,14]$. Buds are, after all, the hydra's way for removing excess cells, and tumors are, if nothing else, masses of excess cells. Metastasis, like asexual reproduction, therefore, would seem to be a consequence of excess cells finding a congenial home.

Of course, hydra's buds are normal and examples of successful tissue cooperation in an advantageous enterprise, while tumor progression, metastasis, invasiveness, and destructiveness suggest a breakdown in tissue cooperation in a damaging, frequently devastating enterprise. The distinction between normal and tumor tissues in vertebrates are not necessarily straightforward, however. Indeed, many tumors seem engaged "in a life/death struggle" to establish a supporting superstructure with adequate circulation. The failure of tumors to find a solution to the problem of self-maintenance would seem a paradigm for the breakdown of tissue cooperation. The failure of tumor and normal tissue to cooperate also suggests a failure of symbiogeny. Instead of cooperation, competition gains the upper hand with disastrous results. The solution may not be to destroy the cancer so much as to bring it back into cooperation.

\section{References}

1. Shostak S, Patel NG, Burnett AL (1965) The role of mesoglea in mass cell movement in Hydra. Devel. Biol 112: 434-450.

2. Shostak S (1967) Bud movement in Hydra. Science 155: 1567-1568.

3. Shostak S (1968) Growth in Hydra viridis. J Exp Zool 169: 431-446.

4. Shostak S, Bisbee JW, Ashkin C, Tammariello Rv (1968) Budding in Hydra viridis. J Exp Zool 169: 423-30.

5. Shostak S (2008) Speculation on the Evolution of Stem Cells. Breast Disease 29: 3-13.

6. Shostak S (2015) Symbiogeny and the Evolution of Tissues: The Hypothesis. Biol Syst Open Access 4:127.

7. Shostak S (2015) How Cnidaria got its cnidocysts. Biol Syst Open Access $4: 139$.

8. Shostak S (2015) Myxozoa in Haeckel's Shadow. Cell Dev Biol 4:155.

9. Shostak S (2015) Evolution of Tissues: Symbiogeny: Biol Sci 14-63.

10. Shostak S, V Kolluri (1995) Symbio genetic origins of cnidaria ncnidocysts.Symbiosis 19:1-29.

11. Shostak S, Landy M (2016) Symbiogeny and the rhizomatic. Trends in Devel Biol 9:17-28.

12. Shostak S (1977) Vegetative reproduction by budding in Hydra: A perspective on tumors. Perspectives in Biology and Medicine 20: 545-568.

13. Shostak S (1993) A symbiogenetic theory for the origins of cnidocysts in Cnidaria. BioSystems 29: 49-58.

14. Shostak S (2017) Hydra's complexity: Budding and cancer. Trends Devel Biol 10: 31-39.
15. Campbell RD (1967) Tissue dynamics of steady state growth in Hydra littoralis. I Patterns of cell division. Devel Biol 15: 487-502.

16. Campbell RD (1974) Cell movements in Hydra. Amer Zool 14: 523-535.

17. Shostak S (1969) Mesoglea. Encyclopedia of Biological Sciences.

18. Shostak S (2000) Cnidaria. In Encyclopedia of Life Sciences.

19. Lentz TL (1966) The Cell Biology of Hydra. New York, USA.

20. Littlefield LC (1985) Germ cells in Hydra oligactis males: I. Isolation of a subpopulation of interstitial cells that is developmentally restricted to sperm production. Dev Biol 112: 185-193.

21. Littlefield CL (1991) Cell lineages in hydra: Isolation and characterization of an interstitial stem cell restricted to egg production in Hydra oligactis. Dev Biol143: 378-388.

22. Campbell RD (1965) Growth and tissue renewal patterns in Hydra littoralis. Thesis, The Rockefeller Institute, New York, USA.

23. Campbell RD (1967) Tissue dynamics of steady state growth in Hydra littoralis. II. Patterns of tissue movement. J Morphol 121: 19-28.

24. Campbell, R.D., 1967c. Tissue dynamics of steady state growth in Hydra littoralis. III. Behavior of specific cell types during tissue movement. J Exp Zool 164: 379-392.

25. Clarkson SG, Wolpert L (1967) Bud morphogenesis in Hydra. Nature 214: 780-783.

26. Bode H (1988) "Control of nematocyte differentiation in Hydra". In: Hessinger DA, Lenhoff HM (eds.). The Biology of Nematocysts. Academic Press, New York, USA.

27. Brien P, Renier-Decoen M (1949) La croissance, la blastogénèse, l'ovogénèse chez Hydra fusca (Pallas). Bull. Biol. Franceet Belg 83: 293396.

28. Burnett AL. (1961) The growth process in Hydra. J Exp Zool 146: 21-84.

29. Otto JJ, Campbell RD (1977) Tissue economics of hydra: regulation of cell cycle, animal size and development by controlled feeding rates. J Cell Sci 28: 117-132.

30. Bisbee JW (1973) Size determination in Hydra: The roles of growth and budding. J ExpMorphol 30: 1-20.

31. Park HD, Ortmeyer AB (1973) Growth and differentiation in hydra. II. The effect of temperature on budding in Hydra littoralis. J Exp Zool 179: 283-288.

32. Martínez DE, Bridge D (2012) Hydra, the everlasting embryo, confronts aging. Int J Dev Biol 56: 479-487.

33. Shostak S (1977) Regeneration in Hydra viridis with multiple-gastric region grafts: reversal of the middle piece. J Morphol 154: 1-17.

34. Campbell RD (1976) Elimination by Hydra interstitial and nerve cells by means of colchicine. J Cell Sci 21: 1-13.

35. David CN, S Murphy (1977) Characterization of interstitial stem cells in hydra by cloning. Dev Biol 58: 372-383.

36. David CN (1982) Eliminating interstitial cells with nitrogen mustard. $H y$ dra: Research Methods Pg no: 299-302.

37. Bode HR (1982) Reducing populations of interstitial cells and nematoblasts with hydroxyurea. Hydra: Research Methods Pg no: 291-294.

38. Novak P (1982) Preparing Hydra viridis with Nerve Cells and No Interstitial Cells, or with Neither of These Cell Types. Hydra: Research Methods Pg no: 295-297.

39. Marcum BA (1982) Culturing epithelial hydra. Hydra: Research Methods Pg no: 287-290. 
40. Aufschnaiter R, Zamir EA, Little CD, Özbek S, Münder S, et al. (2011) In vivo imaging of basement membrane movement: ECM patterning shapes Hydra polyps. J Cell Sci 124: 4027-4038.

41. Campbell RD (1980) The role of muscle processes in Hydra morphogenesis. Pg no: 421-428.

42. Shostak S, Globus M (1966) Migration of Epithelio-muscular Cells in $\mathrm{Hy}$ dra. Nature 210: 218-219.

43. Shostak S (1974) The complexity of hydra: Homeostasis, morphogenesis, controls and integration. Q Rev Biol 49: 287-310.

44. Shostak S (1979) Digestive cell and tentacle number in freshly detached buds of Hydra viridis. Int J Invert Reprod 1: 167-178.

45. Shostak S (1981) Variation in Hydra's tentacle numbers as a function of temperature. Int J Invert Reprod 3: 321-331.

46. Shostak S (1982) Structural cell number and regeneration in Chlorohydra viridissima. J Exp Zool 222: 69-75.

47. Shostak S, Tammariello RV (1969) Supernumerary heads in Hydra viridis. Natl Cancer Inst Monogr 31: 739-750.

48. Shostak S, Adams JA (1975) Morphogenetic gradients in moltiple-graft Hydra viridis. I. The effects of colcemid and colchicine. J Exp Zool 192: 43-56.
49. Aufschnaiter R, Wedlich-Söldner R, Zhang X, Hobmayer B (2017Apical and basal epitheliomuscular F-actin dynamics during Hydra bud evagination. Biol Open 6:1137-1148.

50. Burnett AL, Hausman RE (1969) The mesoglea of hydra. II. Possible role in morphogenesis. J Exp Zool 171: 15-24.

51. Shimizu H, Zhang X, Zhang J, Leontovich A, Fei K, et al. (2002) Epithelial morphogenesis in hydra requires de novo expression of extracellular matrix components and matrix metalloproteinases. Develop 129: 1521-1532.

52. Campbell RD (1979) Development of Hydra lacking interstitial and nerve cells Pg no: 267-93.

53. Sapp J (2010) Saltational symbiosis. Theory Biosci 129: 125-133.

54. Haeckel E (1901) The Riddle of the Universe at the Close of the Nineteenth Century. Nature 63: 320-321.

55. Shostak, S., 1993b. "Cnidaria" pp. 45-105 in Reproductive Biology of Invertebrates Volume VI, Part A: Asexual Propagation and Reproductive Strategies, edited by K.G. and R.G. Adiyodi, New Delhi, India: Oxford \& IBH Publishing]. 


\section{di}

Journal of Anesthesia \& Clinical Care

Journal of Addiction \& Addictive Disorders

Advances in Microbiology Research

Advances in Industrial Biotechnology

Journal of Agronomy \& Agricultural Science

Journal of AIDS Clinical Research \& STDs

Journal of Alcoholism, Drug Abuse \& Substance Dependence

Journal of Allergy Disorders \& Therapy

Journal of Alternative, Complementary \& Integrative Medicine

Journal of Alzheimer's \& Neurodegenerative Diseases

Journal of Angiology \& Vascular Surgery

Journal of Animal Research \& Veterinary Science

Archives of Zoological Studies

Archives of Urology

Journal of Atmospheric \& Earth-Sciences

Journal of Aquaculture \& Fisheries

Journal of Biotech Research \& Biochemistry

Journal of Brain \& Neuroscience Research

Journal of Cancer Biology \& Treatment

Journal of Cardiology: Study \& Research

Journal of Cell Biology \& Cell Metabolism

Journal of Clinical Dermatology \& Therapy

Journal of Clinical Immunology \& Immunotherapy

Journal of Clinical Studies \& Medical Case Reports

Journal of Community Medicine \& Public Health Care

Current Trends: Medical \& Biological Engineering

Journal of Cytology \& Tissue Biology

Journal of Dentistry: Oral Health \& Cosmesis

Journal of Diabetes \& Metabolic Disorders

Journal of Dairy Research \& Technology

Journal of Emergency Medicine Trauma \& Surgical Care

Journal of Environmental Science: Current Research

Journal of Food Science \& Nutrition

Journal of Forensic, Legal \& Investigative Sciences

Journal of Gastroenterology \& Hepatology Research

Journal of Gerontology \& Geriatric Medicine
Journal of Genetics \& Genomic Sciences

Journal of Hematology, Blood Transfusion \& Disorders

Journal of Human Endocrinology

Journal of Hospice \& Palliative Medical Care

Journal of Internal Medicine \& Primary Healthcare

Journal of Infectious \& Non Infectious Diseases

Journal of Light \& Laser: Current Trends

Journal of Modern Chemical Sciences

Journal of Medicine: Study \& Research

Journal of Nanotechnology: Nanomedicine \& Nanobiotechnology

Journal of Neonatology \& Clinical Pediatrics

Journal of Nephrology \& Renal Therapy

Journal of Non Invasive Vascular Investigation

Journal of Nuclear Medicine, Radiology \& Radiation Therapy

Journal of Obesity \& Weight Loss

Journal of Orthopedic Research \& Physiotherapy

Journal of Otolaryngology, Head \& Neck Surgery

Journal of Protein Research \& Bioinformatics

Journal of Pathology Clinical \& Medical Research

Journal of Pharmacology, Pharmaceutics \& Pharmacovigilance

Journal of Physical Medicine, Rehabilitation \& Disabilities

Journal of Plant Science: Current Research

Journal of Psychiatry, Depression \& Anxiety

Journal of Pulmonary Medicine \& Respiratory Research

Journal of Practical \& Professional Nursing

Journal of Reproductive Medicine, Gynaecology \& Obstetrics

Journal of Stem Cells Research, Development \& Therapy

Journal of Surgery: Current Trends \& Innovations

Journal of Toxicology: Current Research

Journal of Translational Science and Research

Trends in Anatomy \& Physiology

Journal of Vaccines Research \& Vaccination

Journal of Virology \& Antivirals

Archives of Surgery and Surgical Education

Sports Medicine and Injury Care Journal

International Journal of Case Reports and Therapeutic Studies

Submit Your Manuscript: http://www.heraldopenaccess.us/Online-Submission.php 